\title{
Pretreatment of Corn Stover Using an Extremely Low-Liquid Ammonia (ELLA) Method for the Effective Utilization of Sugars in Simultaneous Saccharification and Fermentation (SSF) of Ethanol
}

\author{
Tin Diep Trung Le ${ }^{1}$, Vi Phuong Nguyen Truong ${ }^{2}$, My Thi Tra Ngo ${ }^{1}$, Tae Hyun Kim ${ }^{1, * \mathbb{D}}$ \\ and Kyeong Keun $\mathrm{Oh}^{3,4, *(\mathbb{D})}$
}

1 Department of Materials Science and Chemical Engineering, Hanyang University, Ansan, Gyeonggi-do 15588, Korea; trungtin@hanyang.ac.kr (T.D.T.L.); tramy152518@hanyang.ac.kr (M.T.T.N.)

2 Institute of Applied Technology, Thu Dau Mot University, Thu Dau Mot City 820000, Vietnam; vitnp@tdmu.edu.vn

3 R \& D Center, SugarEn Co., Ltd., Yongin, Gyeonggi-do 16890, Korea

4 Department of Chemical Engineering, Dankook University, Yongin, Gyeonggi-do 16890, Korea

* Correspondence: hitaehyun@hanyang.ac.kr (T.H.K.); kkoh@dankook.ac.kr (K.K.O.); Tel.: +82-31-400-5222 (T.H.K.); +82-31-8005-3548 (K.K.O.)

\section{check for} updates

Citation: Le, T.D.T.; Nguyen Truong, V.P.; Ngo, M.T.T.; Kim, T.H.; Oh, K.K. Pretreatment of Corn Stover Using an Extremely Low-Liquid Ammonia (ELLA) Method for the Effective Utilization of Sugars in Simultaneous Saccharification and Fermentation (SSF) of Ethanol. Fermentation 2021, 7, 191. https://doi.org/10.3390/ fermentation7030191

Academic Editor: Jie Bao

Received: 14 August 2021

Accepted: 8 September 2021

Published: 14 September 2021

Publisher's Note: MDPI stays neutral with regard to jurisdictional claims in published maps and institutional affiliations.

Copyright: (c) 2021 by the authors. Licensee MDPI, Basel, Switzerland. This article is an open access article distributed under the terms and conditions of the Creative Commons Attribution (CC BY) license (https:/ / creativecommons.org/licenses/by/ $4.0 /)$.

\begin{abstract}
Extremely low-liquid ammonia (ELLA) pretreatment using aqueous ammonia was investigated in order to enhance the enzymatic saccharification of corn stover and subsequent ethanol production. In this study, corn stover was treated with an aqueous ammonia solution at different ammonia loading rates $\left(0.1,0.2\right.$, and $0.3 \mathrm{~g} \mathrm{NH}_{3} / \mathrm{g}$ biomass $)$ and various liquid-to-solid (L/S) ratios $(0.55$, 1.12 , and 2.5). The ELLA pretreatment was conducted at elevated temperatures $\left(90-150{ }^{\circ} \mathrm{C}\right)$ for an extended period (24-120 h). Thereafter, the pretreated material was saccharified by enzyme digestion and subjected to simultaneous saccharification and fermentation (SSF) tests. The effects of key parameters on both glucan digestibility and xylan digestibility were analyzed using analysis of variance (ANOVA). Under optimal pretreatment conditions ( $\mathrm{L} / \mathrm{S}=2.5,0.1 \mathrm{~g}-\mathrm{NH}_{3} / \mathrm{g}$-biomass, $150{ }^{\circ} \mathrm{C}$ ), $81.2 \%$ glucan digestibility and $61.1 \%$ xylan digestibility were achieved. The highest ethanol yield achieved on the SSF tests was $85.4 \%$. The ethanol concentration was $14.5 \mathrm{~g} / \mathrm{L}$ at $96 \mathrm{~h}$ (pretreatment conditions: liquid-to-solid ratio $(\mathrm{L} / \mathrm{S})=2.5,0.1 \mathrm{~g}-\mathrm{NH}_{3} / \mathrm{g}$-biomass, $150^{\circ} \mathrm{C}, 24 \mathrm{~h}$. SSF conditions: microorganism Saccharomyces cerevisiae $\left(\mathrm{D}_{5} \mathrm{~A}\right), 15 \mathrm{FPU} /$ g-glucan, CTech2, 3\% w/v glucan, $\left.37^{\circ} \mathrm{C}, 150 \mathrm{rpm}\right)$.
\end{abstract}

Keywords: liquid ammonia; corn stover; alkaline pretreatment; enzyme digestibility; lignocellulosic biomass; simultaneous saccharification and fermentation (SSF)

\section{Introduction}

The declining supply of fossil fuels, the increasing population, and global industrialization have triggered an increase in the demand for alternate fuels. To address this problem, most green research in recent years has focused on the development of second-generation bioethanol [1].

Second-generation biofuels are made from lignocellulosic biomass or woody crops, mostly from agricultural residues or waste [2]. The extraction of fuel from this type of biomass is difficult because of the recalcitrant nature of lignocellulosic materials, which include agricultural residues, such as corn stover, rice straw, wheat straw, sugar cane, and sweet sorghum. The use of lignocellulosic fuel can help to overcome the problems associated with first-generation biofuels (such as the competition between food and fuel) [3]. Moreover, it can supply a large proportion of the global fuel demand sustainably, inexpensively, and with substantial environmental benefits $[4,5]$. The production of ethanol 
from complex sugars in leaves and stalks is promising for radically broadening the range of possible ethanol feedstock [6].

Corn stover is a promising lignocellulosic biomass feedstock and agricultural byproduct. It consists of the husk, cob, leaves, and stalk left in the fields after a grain harvest. Approximately more than half of the dry weight of this biomass is made up of sugars, indicating its potential as a feedstock for ethanol production. Corn-based ethanol is currently the dominant form of ethanol used in the United States $[7,8]$. Ethanol fuel from other sources is being developed, and some sources may soon be utilized for commercial production $[9,10]$.

Lignocellulosic feedstocks contain useful sugars that are locked in by lignin, hemicellulose, and cellulose. These are complex carbohydrates, with considerable variations in the relative amounts of each structural component. Furthermore, the cellulose, hemicellulose, and lignin in the cell walls lead to different physical properties, such as cell wall thickness and porosity, depending on the specific plant species [11]. Previous studies have reported that plant cell walls in lignocellulosic biomass are highly resistant to chemical, physical, and enzymatic degradation $[12,13]$. Therefore, pretreatment is necessary to disrupt the recalcitrant structure of plant cell walls, allowing easy access to sugars, which can later be fermented to produce ethanol in the same way as in first-generation biofuel production [14]. Among the various pretreatment methods, alkaline pretreatment is known to be effective in the removal of lignin from lignocellulosic biomass and the transformation of the physico-chemical structure into one that is more digestible by enzymes [15,16]. Ammonia is chemically reactive enough to cause significant morphological changes in biomass other than delignification. Among the alkali pretreatments, the method of using ammonium hydroxide was studied for reasons such as easy recovery, non-corrosiveness, and nontoxicity [15]. Previous studies have focused on using enzymes or chemical pretreatments to properly utilize lignocellulosic sugars for the production of bioethanol. Low-moisture anhydrous ammonia (LMAA) pretreatment can reduce ammonia and water input by using anhydrous ammonia gas without a washing step. However, anhydrous ammonia gas must be stored and handled at a high pressure, which requires specifically designed and wellmaintained equipment $[17,18]$. The extremely low-liquid ammonia (ELLA) method has been proposed to solve the problems associated with processes that use gaseous ammonia in our laboratory [19]. In this ELLA pretreatment, ammonium hydroxide was added to the biomass in the preconditioning step and then pretreated at an elevated temperature for a certain period. The excess ammonia was then evaporated, and the pretreated biomass was subjected to enzymatic saccharification and fermentation without a washing step. The ELLA method is believed to be economical because it requires minimal chemical input. Moreover, a liquid mist form of ammonia is easy to handle, making its use feasible for large-scale commercialization in biorefineries.

In this study, the extremely low-liquid ammonia (ELLA) method was proposed to treat herbaceous biomass, specifically corn stover. Aqueous ammonia was applied in the form of mist directly on the corn stover, which was then placed in a tumble drum mixer for the uniform mixing of corn stover treated with aqueous ammonia, and then reacted at elevated temperatures $\left(90-150{ }^{\circ} \mathrm{C}\right.$ for $\left.24-120 \mathrm{~h}\right)$. This method enhanced the enzymatic saccharification of corn stover and aimed at evaluating the effect of ELLA treatment on SSF in the production of ethanol.

\section{Materials and Methods}

\subsection{Materials}

\subsubsection{Feedstock}

The corn stover was supplied by CJ Cheiljedang (Seoul, Korea). It was air-dried at room temperature $\left(\sim 25^{\circ} \mathrm{C}\right)$, ground, and sieved. The size of this ground biomass was 10-35 Tyler mesh. The initial compositions (Table 1 ) were determined by the standard laboratory analytical procedure (LAP) of the National Renewable Energy Laboratory (NREL, Golden City, CO, USA). 
Table 1. Composition of corn stover ${ }^{1,2}$.

\begin{tabular}{ccc}
\hline & Component. & Composition [wt.\%] \\
\hline & Glucose & $0.6 \pm 0.2$ \\
Extractives & Fructose & $0.2 \pm 0.2$ \\
& Galactose & $0.6 \pm 0.0$ \\
& Sucrose & $0.2 \pm 0.0$ \\
& Soluble lignin & $0.6 \pm 0.0$ \\
& Other extractives & $0.4 \pm 0.0$ \\
Extractive free-solid & Glucan & $15.2 \pm 0.0$ \\
\hline & Xylan & $34.8 \pm 1.6$ \\
& Arabinan & $17.6 \pm 0.1$ \\
& Manan & $1.7 \pm 0.2$ \\
& Galactan & $3.1 \pm 0.0$ \\
& AIL & $2.1 \pm 0.2$ \\
& ASL & $14.1 \pm 0.1$ \\
& Ash & $1.8 \pm 0.0$ \\
& Protein & $0.6 \pm 0.1$ \\
& Total sum & $6.6 \pm 0.0$ \\
\hline
\end{tabular}

${ }^{1}$ All weight percentages were calculated based on ODW (oven dry weight) biomass. ${ }^{2}$ The data in the table show the mean value $(n=3)$ and S.D. (standard deviation). ${ }^{3}$ AIL: Acid insoluble lignin; ${ }^{4}$ ASL: Acid soluble lignin.

\subsubsection{Chemicals}

Ammonium hydroxide (Cat. no. 13370-1280, ammonia concentration $\geq 28.0 \%$ ) was purchased from Junsei Chemical Co., Ltd. (Tokyo, Japan) and was used for the ammonia mist pretreatment. Sulfuric acid (Cat. no. 258105-500ML, ACS reagent: Assay 95-98\%) was purchased from Sigma-Aldrich (St. Louis, MO, USA) and used to prepare dilute acid solutions for solid analysis. Avicel ${ }^{\circledR}$ PH-101 (lot \#BCBJ029V) was purchased from SigmaAldrich (St. Louis, MO, USA) and used as a control sample in the enzyme digestibility test.

\subsubsection{Enzyme}

Novozymes Cellic ${ }^{\circledR}$ CTech2 (batch no. VCP10006, Novozymes Inc., Bagsvaerd, Denmark) was used for the enzymatic hydrolysis of pretreated corn stover. The average activity of the enzyme, as determined by LAP NREL, was 88.91 filter paper unit (FPU)/mL.

\subsubsection{Microorganism}

Saccharomyces cerevisiae $\mathrm{D}_{5} \mathrm{~A}$ (ATCC ${ }^{\circledR}$ 200062, American Type Culture Collection (ATCC), Manassas, VA, USA) were cultured in a $100 \mathrm{~mL}$ YPD (yeast extract, peptone, and dextrose) solid medium containing $2.0 \%$ yeast extract (cat no. 212750, BD Inc., Franklin Lakes, NJ, USA), 1.0\% peptone (cat no. 211677, BD Inc., Franklin Lakes, NJ, USA), 2.0\% dextrose, and $1.5 \%$ agar [10]. After autoclaving the solid medium at $121^{\circ} \mathrm{C}$ for $15 \mathrm{~min}$, the plate was poured and allowed to solidify. S. cerevisiae $\mathrm{D}_{5} \mathrm{~A}$ was transferred every month and stored in a refrigerator at $4{ }^{\circ} \mathrm{C}$.

\subsection{Methods}

\subsubsection{Pre-Conditioning}

To adjust the ammonia loading at different target levels ( $\mathrm{L} / \mathrm{S}=0.55,1.12$, and 2.5), ammonium hydroxide solutions were added. After the ammonium hydroxide was sprayed, corn stover (100 g oven-dry basis) was homogenized at $30 \mathrm{rpm}$ for $1 \mathrm{~h}$ in a tumbler mixer.

\subsubsection{Chemical Pretreatment at Elevated Temperatures}

Corn stover (10 g oven-dry basis) was treated with aqueous ammonia and stored in a small sealed-batch reactor. The reactor (whose internal volume was $105.9 \mathrm{~cm}^{3}$ ) was constructed with a length of $30 \mathrm{~cm}$, an outer diameter of $2.54 \mathrm{~cm}$, and a tube wall thickness of $0.21 \mathrm{~cm}$. Sealed batch reactors were carefully tightened to prevent ammonia leakage. The 
ammoniated corn stover was pretreated at elevated temperatures $\left(90,120\right.$, and $\left.150{ }^{\circ} \mathrm{C}\right)$ and at different periods of time $(24,48,72,96$, and $120 \mathrm{~h})$ using a forced convection drying oven (model: OF-12G, Jeio Tech Co., Ltd., Daejeon, Korea). All experiments were performed in duplicate.

\subsubsection{Catalyst Recovery}

After pretreatment, the reactors were cooled to $25^{\circ} \mathrm{C}$, and then opened in order to transfer the treated corn stover into a wide tray. Excess ammonia from the treated corn stover was allowed to evaporate in a fume hood for $1 \mathrm{~h}$ at $25^{\circ} \mathrm{C}$. Approximately $1 \mathrm{~g}$ of treated corn stover was collected for analyzing the residual ammonia.

\subsubsection{Enzyme Saccharification}

The enzymatic digestibility of corn stover was determined in duplicates. Rubbercapped $250 \mathrm{~mL}$ Erlenmeyer flasks were filled with a $100 \mathrm{~mL}$ liquid (total working volume) and 1.0 g glucan solid loading. The reaction conditions were 15 FPU/g glucan per sample. Samples were tested in a shaker incubator (model: VS-8480SFN, Vision Scientific Co., Ltd., Daejeon, Korea) under stable conditions $\left(50 \pm 1{ }^{\circ} \mathrm{C}, \mathrm{pH} 4.8\right.$, and $\left.150 \mathrm{rpm}\right)$. The total glucose content after $72 \mathrm{~h}$ of hydrolysis was used to calculate enzymatic digestibility. Untreated corn stover and Avicel ${ }^{\circledR}$ PH-101 (lot \#BCBJ029V) were examined under the same digestibility test conditions as the control samples.

\subsubsection{Simultaneous Saccharification and Fermentation (SSF)}

An inoculum preparation of $S$. cerevisiae was transferred into $100 \mathrm{~mL}$ of sterile YPD medium without agar. The medium contained no antibiotics and was sterilized by autoclaving at $121^{\circ} \mathrm{C}$ for 15 min (autoclave model: ST-85G, Jeio Tech Co., Ltd., Daejeon, Korea). The inoculum flask was incubated at $37^{\circ} \mathrm{C}$ and $150 \mathrm{rpm}$ in an incubator shaker. When the glucose concentration decreased below $2.0 \mathrm{~g} / \mathrm{L}$, cells were collected by centrifugation at $3000 \mathrm{rpm}$ for $5 \mathrm{~min}$. After a $24 \mathrm{~h}$ incubation, the dry cell mass (DCM) reached 2.9-3.0 g/L and the viability test was performed by cell counting. The colony forming unit (CFU) tests using YPD media were $10^{6}-10^{7} \mathrm{CFU} / \mathrm{mL}$.

All the equipment used in the SSF experiment was sterilized at $121{ }^{\circ} \mathrm{C}$ for $15 \mathrm{~min}$ using an autoclave. The experiment, which was performed in duplicate, used $250 \mathrm{~mL}$ flasks, which were capped with rubber caps that were perforated with a syringe needle to vent $\mathrm{CO}_{2}$. The flasks were agitated at $150 \mathrm{rpm}$ in an incubator shaker at $37{ }^{\circ} \mathrm{C}$. The initial biomass loading was 3.0\% w/v glucan, a YP 5x medium containing $2.0 \%$ yeast extract (Cat. no. 212750, BD Inc., Franklin Lakes, NJ, USA), 1\% peptone (Cat. no. 211677, BD Inc., Franklin Lakes, NJ, USA), and a typical enzyme loading of 15 FPU/g-glucan. The pH was maintained at 4.8. The experiment was performed in an incubator shaker for 5 days $(120 \mathrm{~h})$ at $37^{\circ} \mathrm{C}$. Samples of approximately $1 \mathrm{~mL}$ were collected from each flask every $24 \mathrm{~h}$, centrifuged, and tested for sugars, ethanol, and acetic acid using a high performance liquid chromatography (HPLC, model: LC-10A, Shimadzu Inc., Kyoto, Japan) equipped with a Bio-Rad Aminex HPX-87P Column (catalog number 1,250,098, Bio-Rad Inc., Hercules, CA, USA) and a refractive index detector (model RID-10A, Shimadzu Inc., Kyoto, Japan). The mobile phase involved water $(0.5 \mathrm{~mL} / \mathrm{min})$, and a column temperature of $65^{\circ} \mathrm{C}$.

The theoretical maximum ethanol yield in SSF test was calculated as follows:

$$
\text { Ethanol yield }[\%]=\frac{\text { Ethanol produced }[\mathrm{g}] \text { in reactor }}{\text { Initial sugar loading in reactor }[\mathrm{g}] \times 0.511} \times 100
$$

The sum of initial sugar loading was considered as glucose plus xylose in the SSF test.

\subsection{Analytical Method}

\subsubsection{Composition Analysis}

A Soxhlet extractor was used to determine the water and ethanol extracts from the corn stover, and the extractions were conducted for 8 and $24 \mathrm{~h}$, respectively. The com- 
position of the corn stover was analyzed for sugars, lignin, acid-soluble lignin (using a UV spectrophotometer at $320 \mathrm{~nm}$ ), and acid-insoluble lignin and ash (gravimetric method using muffle furnace, $575^{\circ} \mathrm{C}$ ), following the standard LAP of NREL. The carbohydrates were determined by an HPLC (model LC-10A, Shimadzu Inc., Kyoto, Japan) equipped with a Bio-Rad Aminex HPX-87P column (Cat. no. 1250098, Bio-Rad Inc., Hercules, CA, USA) and a refractive index detector (model RID-10A, Shimadzu Inc., Kyoto, Japan). The mobile phase involved water $(0.5 \mathrm{~mL} / \mathrm{min})$, and a column temperature of $65^{\circ} \mathrm{C}$.

\subsubsection{Residual Ammonia Analysis}

Approximately $0.3 \mathrm{~g}$ of ammoniated corn stover was placed in a glass bottle with $80 \mathrm{~mL}$ of $1 \%$ boric acid solution. These glass bottles were placed in an oven at a stable temperature $\left(80^{\circ} \mathrm{C}\right)$ for $24 \mathrm{~h}$. After $24 \mathrm{~h}$, the glass bottle with residual ammonia in the liquid was removed from the oven. The liquid and solid were separated by filtration using a filter paper (Fisher catalogue number F2044-090, size: $90 \mathrm{~mm} \varnothing$, pack: 100 units from $\mathrm{CHmlab}$ Group, Barcelona, Spain). Thereafter, the filtrate was diluted to a $100 \mathrm{~mL}$ working volume. The liquid containing ammonia was reacted with a sodium hydroxide solution $(10 \mathrm{~N} \mathrm{NaOH})$. The residual ammonia was determined using an ammonia analyzer (model: Accumet ${ }^{\circledR}$ XL250, Dual Channel pH/mV/Ion, Thermo Fisher Scientific Inc., Tampa, FL, USA) and an ion-selective electrode (ISE, Cat. no. 13620509, Thermo Fisher Scientific Inc., Tampa, FL, USA).

\section{Results and Discussions}

3.1. Effects of Elevated Temperature, Ammonia Concentration, and Pretreatment Temperature on Compositions and Enzymatic Digestibility

The initial compositions were determined following the NREL, and they are summarized in Table 1. The initial moisture content of the corn stover was approximately $8.5 \%$. The composition of the treated corn stover was affected by the temperature during the experiments. The ELLA pretreatment was not expected to result in any significant changes in the biomass composition at a mild temperature $\left(90\right.$ and $\left.120^{\circ} \mathrm{C}\right)$. Furthermore, the corn stover treated at a higher temperature $\left(150^{\circ} \mathrm{C}\right)$ showed an interesting change in its composition (Figure 1), indicating that higher temperatures can influence the composition of treated corn stover. For example, acid soluble lignin (ASL) and acid insoluble lignin (AIL) increased from $2.9 \%$ to $3.5 \%$ and $17.8 \%$ to $23.7 \%$, respectively, whereas xylan decreased from $21.8 \%$ to $17.0 \%\left(0.1 \mathrm{~g}-\mathrm{NH}_{3} / \mathrm{g}\right.$-biomass, $\left.150{ }^{\circ} \mathrm{C}, \mathrm{L} / \mathrm{S}=1.12\right)$; these observations are the same as those made in a previous study [6]. In the ELLA pretreatment, the biomass treated at $120-150{ }^{\circ} \mathrm{C}$ showed a considerable change in its composition; both insoluble lignin and soluble lignin increased, whereas xylan and arabinan decreased $[10,20]$. It is known that hemicelluloses are typically less ordered; that is, they are more amorphous than cellulose and more easily hydrolyzed to monomers by chemicals or enzymes. Xylan and arabinan are the main components of hemicellulose; however, under common pretreatment conditions, particularly with chemicals such as ammonia combined with heat pretreatment, they can easily be degraded.

The enzymatic hydrolysis of lignocellulosic biomass can be influenced by the effectiveness of the enzymes and the physical, chemical, and morphological characteristics of the biomass. Therefore, as shown in Table 2, temperature can also affect glucan digestibility. There were a statistically significant difference $(p$-value $<0.05)$ and a close-to-statisticallysignificant difference in the composition of the biomass $(p$-value $=0.0516)$ associated with increasing temperature in the ELLA pretreatment. 


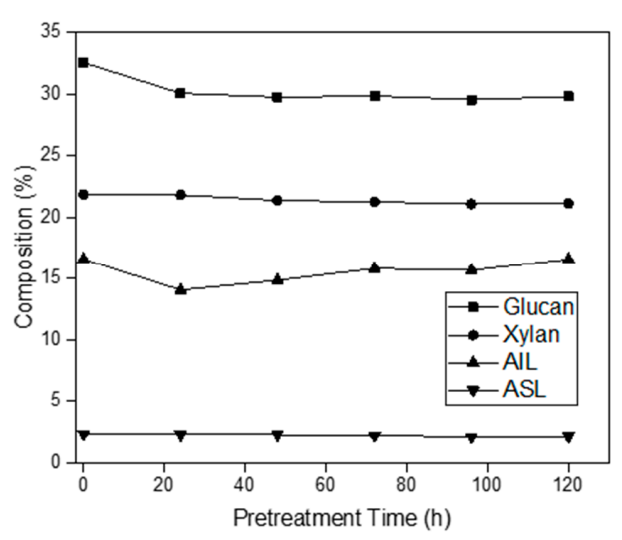

(a)

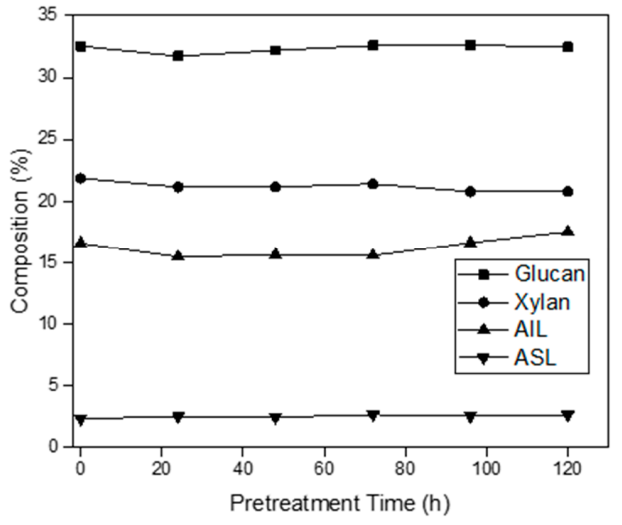

(b)

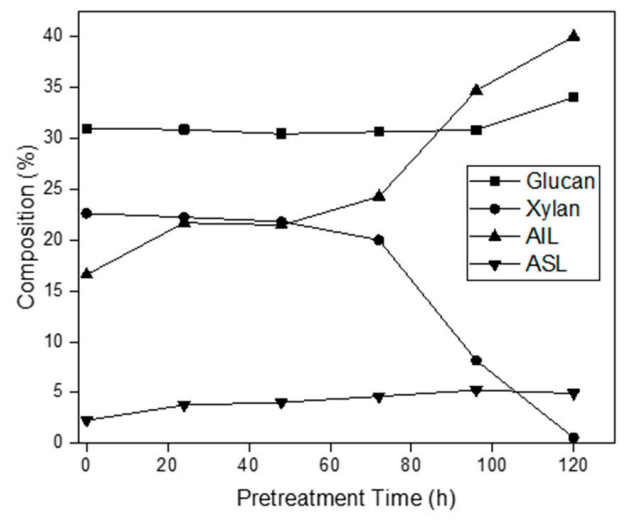

(c)

Figure 1. Effect of temperature on compositions of ELLA-treated corn stover. Treatment conditions: (a) ELLA treatment: $\mathrm{L} / \mathrm{S}=0.55,90{ }^{\circ} \mathrm{C}, 0.08$ g-NH $3 /$ g-biomass; (b) ELLA treatment: $\mathrm{L} / \mathrm{S}=0.55,120{ }^{\circ} \mathrm{C}, 0.1 \mathrm{~g}-\mathrm{NH}_{3} / \mathrm{g}$-biomass; and (c) ELLA treatment: $\mathrm{L} / \mathrm{S}=0.55,150^{\circ} \mathrm{C}, 0.1 \mathrm{~g}-\mathrm{NH}_{3} / \mathrm{g}$-biomass; ASL (acid soluble lignin) and AIL (acid insoluble lignin).

Table 2. ANOVA results of glucan digestibility at different pretreatment temperatures.

\begin{tabular}{|c|c|c|c|c|c|c|c|}
\hline $\begin{array}{c}\text { Groups } \\
\text { (Temp \& L/S) }\end{array}$ & Mean & Variance & Std. Dev. & Low & High & $F$ & $p$-Value \\
\hline $90{ }^{\circ} \mathrm{C}, 0.55$ & 75.5 & 3.3 & 1.8 & 73.7 & 77.3 & \multirow{3}{*}{9.6} & \multirow{3}{*}{0.0032} \\
\hline $120^{\circ} \mathrm{C}, 0.55$ & 84.8 & 2.9 & 1.7 & 83.1 & 86.5 & & \\
\hline $150{ }^{\circ} \mathrm{C}, 0.55$ & 83.7 & 33.9 & 5.8 & 77.9 & 89.5 & & \\
\hline $90^{\circ} \mathrm{C}, 1.12$ & 82.2 & 55.6 & 7.5 & 74.7 & 89.6 & \multirow{3}{*}{3.2} & \multirow{3}{*}{0.0516} \\
\hline $120^{\circ} \mathrm{C}, 1.12$ & 84.0 & 27.9 & 5.3 & 78.8 & 89.3 & & \\
\hline $150{ }^{\circ} \mathrm{C}, 1.12$ & 77.9 & 54.5 & 7.4 & 70.6 & 85.3 & & \\
\hline $90^{\circ} \mathrm{C}, 2.50$ & 83.0 & 11.5 & 3.4 & 79.6 & 86.4 & \multirow{3}{*}{3.4} & \multirow{3}{*}{0.0414} \\
\hline $120^{\circ} \mathrm{C}, 2.50$ & 82.1 & 53.9 & 7.3 & 74.8 & 89.5 & & \\
\hline $150^{\circ} \mathrm{C}, 2.50$ & 77.7 & 39.0 & 6.2 & 71.5 & 83.9 & & \\
\hline
\end{tabular}

Note. ELLA treatment: 0.1-0.3 g-NH $/$ g-biomass, $90-150{ }^{\circ} \mathrm{C}, 24-120 \mathrm{~h}$.

Ammonia concentrations of $0.1-0.3$ g- $\mathrm{NH}_{3} / \mathrm{g}$-biomass did not cause any significant changes in the composition of the corn stover at mild temperatures $\left(90-120^{\circ} \mathrm{C}\right)$. However, $0.3 \mathrm{~g}-\mathrm{NH}_{3} / \mathrm{g}$-biomass at $150{ }^{\circ} \mathrm{C}$ led to a significant change in sugars and lignin. Table 3 shows the analysis of variance results of enzymatic digestibility at varying ammonia loading rates. There was a significant difference in biomass composition $(p<0.05)$ when changing the ammonia concentration from 0.1 to $0.3 \mathrm{~g}-\mathrm{NH}_{3} / \mathrm{g}$-biomass at $\mathrm{L} / \mathrm{S}=1.12$ and 2.50 . The enzymatic digestibility results in Figure 2 indicate the effects of ammonium hydroxide 
on the enzymatic digestibility. As discussed in previous research, alkaline treatments such as the use of ammonia solution can remove lignin and thereby increase the digestibility of cellulose [15]. We observed that increasing the ammonia concentration $\left(0.1-0.3 \mathrm{~g}-\mathrm{NH}_{3} / \mathrm{g}\right.$ biomass) proportionally increased the enzymatic digestibility. As shown in Figure 2, glucan digestibility increased from $74 \%$ to $88.2 \%$, and xylan digestibility increased from $54.6 \%$ to $64.8 \%$. It can therefore be inferred that increasing the ammonia concentration caused the ester linkages in the hemicellulose and lignin in the biomass to be easily broken down under elevated temperatures, which consequently significantly improved the enzymatic hydrolysis of the corn stover. However, the treated corn stover at $150{ }^{\circ} \mathrm{C}, 0.3 \mathrm{~g}-\mathrm{NH}_{3} / \mathrm{g}$ biomass, with $72-120 \mathrm{~h}$ of pretreatment, obtained lower glucan digestibility results than those pretreated for 24 and $48 \mathrm{~h}$. This may be because of the residual lignin content in the biomass samples at high temperature $\left(150{ }^{\circ} \mathrm{C}\right)$, maximum ammonia concentrations (0.3 $\mathrm{g}-\mathrm{NH}_{3} / \mathrm{g}$-biomass), and longer pretreatment durations (72-120 h) inhibiting enzymatic hydrolysis (Figure 3). Previous studies found that the residual lignin content in biomass after pretreatment negatively affected enzymatic digestibility [21]. Figure 3 shows the inhibition of lignin during hydrolysis. When the lignin content increased during pretreatment at a high temperature $\left(150^{\circ} \mathrm{C}\right)$, a significant drop in glucan digestibility was observed.

Table 3. ANOVA results of glucan and xylan digestibility tests at different ammonia concentrations.

\begin{tabular}{|c|c|c|c|c|c|c|c|}
\hline $\begin{array}{l}\text { Group } \\
\text { (g-NH} / \text { g-Biomass \& L/S) }\end{array}$ & Mean & Variance & Std. Dev. & Low & High & $F$ & $p$-Value \\
\hline \multicolumn{8}{|l|}{ Glucan digestibility } \\
\hline $0.1 \mathrm{~g}, 1.12$ & 73.88 & 18.08 & 4.25 & 69.63 & 78.14 & \multirow{3}{*}{28.96} & \multirow{3}{*}{$10^{-8}$} \\
\hline $0.2 \mathrm{~g}, 1.12$ & 86.03 & 32.66 & 5.72 & 80.31 & 91.74 & & \\
\hline $0.3 \mathrm{~g}, 1.12$ & 84.25 & 16.05 & 4.01 & 80.24 & 88.25 & & \\
\hline $0.1 \mathrm{~g}, 2.50$ & 84.81 & 15.39 & 3.92 & 80.89 & 88.74 & \multirow{3}{*}{6.43} & \multirow{3}{*}{0.0036} \\
\hline $0.2 \mathrm{~g}, 2.50$ & 80.47 & 55.42 & 7.45 & 73.02 & 87.91 & & \\
\hline $0.3 \mathrm{~g}, 2.50$ & 77.57 & 22.28 & 4.72 & 72.85 & 82.29 & & \\
\hline \multicolumn{8}{|l|}{ Xylan digestibility } \\
\hline $0.1 \mathrm{~g}, 1.12$ & 62.24 & 18.40 & 4.29 & 57.95 & 66.53 & \multirow{3}{*}{22.64} & \multirow{3}{*}{$10^{-7}$} \\
\hline $0.2 \mathrm{~g}, 1.12$ & 69.53 & 6.69 & 2.59 & 66.94 & 72.11 & & \\
\hline $0.3 \mathrm{~g}, 1.12$ & 65.15 & 1.71 & 1.31 & 63.84 & 66.45 & & \\
\hline $0.1 \mathrm{~g}, 2.50$ & 65.59 & 30.01 & 5.48 & 60.11 & 71.07 & \multirow{2}{*}{4.38} & \multirow{2}{*}{0.0187} \\
\hline $0.1 \mathrm{~g}, 2.50$ & 61.13 & 17.35 & 4.17 & 56.97 & 65.30 & & \\
\hline
\end{tabular}

Note. ELLA treatment: $\mathrm{L} / \mathrm{S}=1.12,2.50,0.1-0.3 \mathrm{~g}-\mathrm{NH}_{3} / \mathrm{g}$-biomass, $90-150{ }^{\circ} \mathrm{C}, 24-120 \mathrm{~h}$, Std. Dev: Standard deviation.

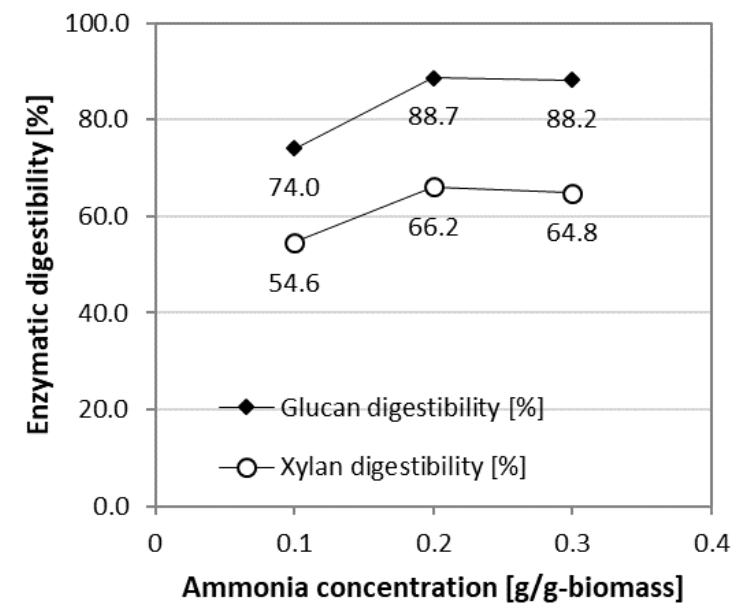

Figure 2. Effect of ammonia concentration on enzymatic digestibility of corn stover. Treatment conditions as follows. Extremely low-liquid ammonia treatment: $\mathrm{L} / \mathrm{S}=1.12,0.1-0.3 \mathrm{~g}-\mathrm{NH}_{3} / \mathrm{g}$ biomass, $120^{\circ} \mathrm{C}, 24 \mathrm{~h}$. Enzymatic hydrolysis conditions: CTech2; $15 \mathrm{FPU} / \mathrm{g}$-glucan loading; $50{ }^{\circ} \mathrm{C}$; $150 \mathrm{rpm}$; hydrolysis time, $72 \mathrm{~h}$. 

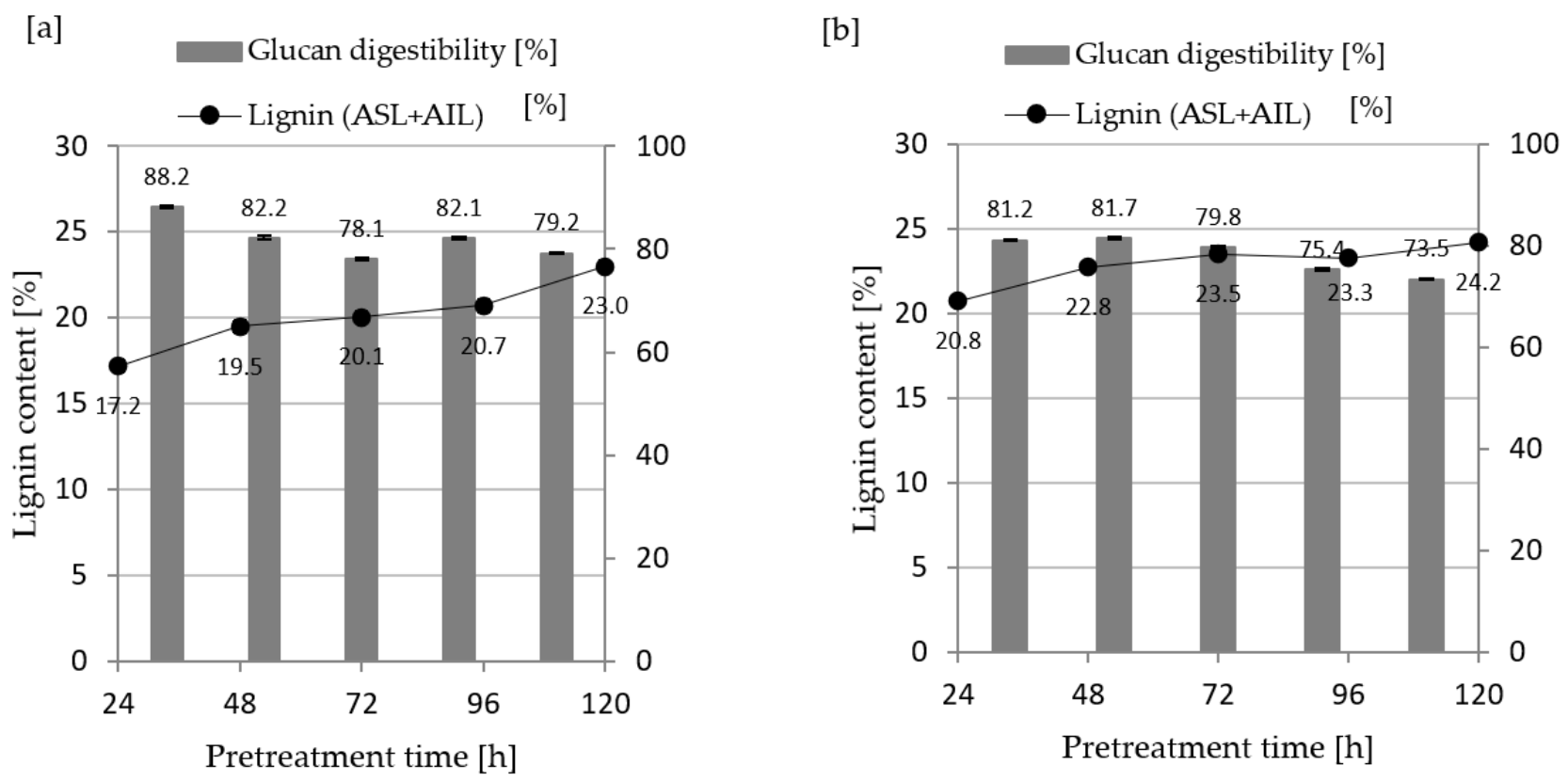

Figure 3. Effect of lignin content on enzymatic digestibility of corn stover. Treatment conditions: (a) ELLA treatment: $\mathrm{L} / \mathrm{S}=1.12,0.3 \mathrm{~g}-\mathrm{NH}_{3} / \mathrm{g}$-biomass, $150{ }^{\circ} \mathrm{C}, 24-120 \mathrm{~h}$; and (b) ELLA treatment: $\mathrm{L} / \mathrm{S}=2.5,0.3 \mathrm{~g}-\mathrm{NH}_{3} / \mathrm{g}$-biomass, $150{ }^{\circ} \mathrm{C}$, 24-120 h. ASL: acid soluble lignin; AIL: acid insoluble lignin. Enzymatic hydrolysis conditions: CTech2; 15 FPU/g-glucan loading; $50{ }^{\circ} \mathrm{C}, 150 \mathrm{rpm}$; hydrolysis time, $72 \mathrm{~h}$.

\subsection{Effect of Liquid-to-Solid Ratio (L/S) on Compositions and Enzymatic Digestibility}

$\mathrm{L} / \mathrm{S}$ ratios, which are defined as the ratio of the oven-dry weight of biomass to that of the ammonia and water, were varied to $0.55,1.12$, and 2.50 . Their effect on the composition and enzymatic digestibility of the corn stover was studied. The glucan content changed little during pretreatment; by contrast, the xylan, arabinan, and lignin contents changed with the L/S ratio, particularly at $\mathrm{L} / \mathrm{S}=0.55$ (Figure 4). For example, the xylan and arabinan contents considerably decreased (xylan from $22.3 \%$ to $0.6 \%$, arabinan from $2.9 \%$ to $0.07 \%$ ), whereas the lignin content increased remarkably (from $25.5 \%$ to $44.9 \%$ ). In addition, at $\mathrm{L} / \mathrm{S}=1.12$ and 2.50 , the xylan, arabinan, and lignin contents changed, but they were not significantly different from those under treatment at $\mathrm{L} / \mathrm{S}=0.55$. We can conclude that under ELLA pretreatment, the L/S ratio significantly affected the pretreatment effects, which was different from the effects observed under LMAA pretreatment. In LMAA, significant effects were not observed when the L/S ratio was changed from 0.2 to 1.5 [22].

As shown in Table 4 , the $p$-value $=0.95>0.05$, which indicates a statistically insignificant difference between the groups for glucan digestibility upon varying the L/S ratio; otherwise, there was a significant difference $(p<0.05)$ between the groups for xylan digestibility. It can be inferred that varying the $\mathrm{L} / \mathrm{S}$ ratio affected xylan digestibility; however, this did not affect glucan digestibility.

The effect of the L/S ratio on the enzymatic digestibility of the corn stover is shown in Figure 5 . It was observed that at $0.1 \mathrm{~g}-\mathrm{NH}_{3} / \mathrm{g}$-biomass, glucan digestibility was the highest for samples with $\mathrm{L} / \mathrm{S}=2.5$ compared to other $\mathrm{L} / \mathrm{S}$ ratios $(0.55,1.12)$. However, when increasing the ammonia loading from 0.2 to $0.3 \mathrm{~g}-\mathrm{NH}_{3} / \mathrm{g}$-biomass (Figure $5 \mathrm{~b}, \mathrm{c}$ ), the glucan digestibility at 2.50 was slightly lower than that at $\mathrm{L} / \mathrm{S}=1.12$. For example, at $\mathrm{L} / \mathrm{S}=1.12$, $0.2 \mathrm{~g}-\mathrm{NH}_{3} / \mathrm{g}$-biomass, $90^{\circ} \mathrm{C}$, and $48 \mathrm{~h}$, the highest glucan digestibility was $92.1 \%$ and xylan digestibility was $73 \%$, whereas the highest glucan and xylan digestibilities were $87.2 \%$ and $70.2 \%$, respectively, at $\mathrm{L} / \mathrm{S}=2.5,0.2 \mathrm{~g}-\mathrm{NH}_{3} / \mathrm{g}$-biomass, $120^{\circ} \mathrm{C}, 72 \mathrm{~h}$. As shown in Figure 5, in most cases, the samples pretreated at $120^{\circ} \mathrm{C}$ showed the highest digestibility. 
[a]

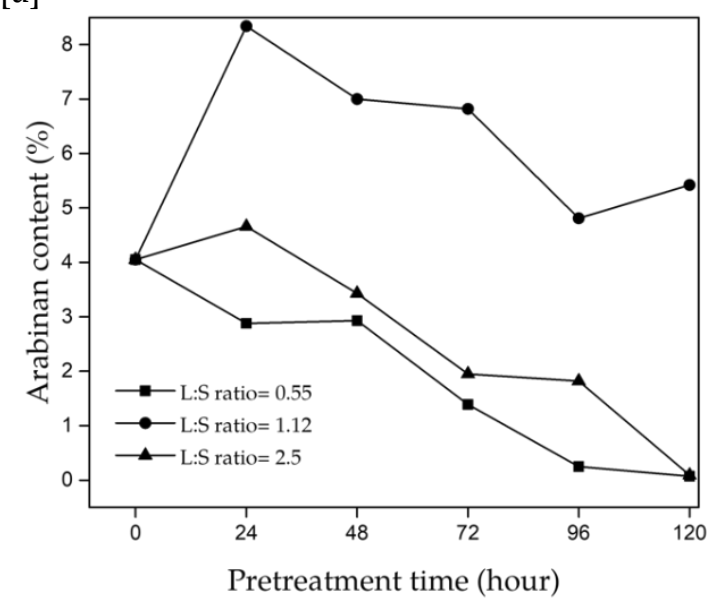

[c]

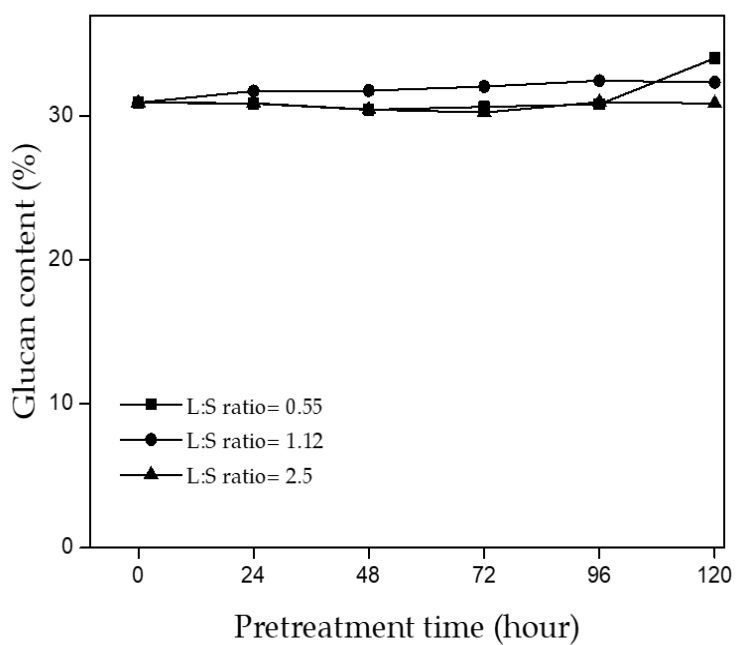

[b]

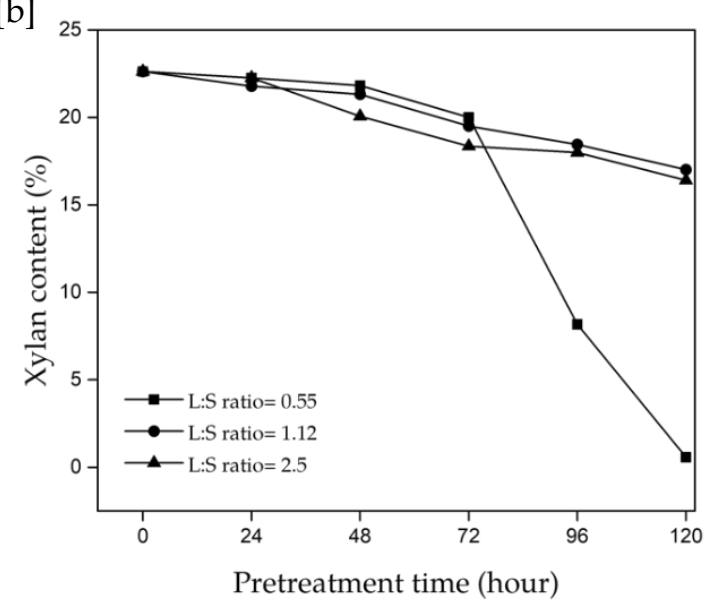

[d]

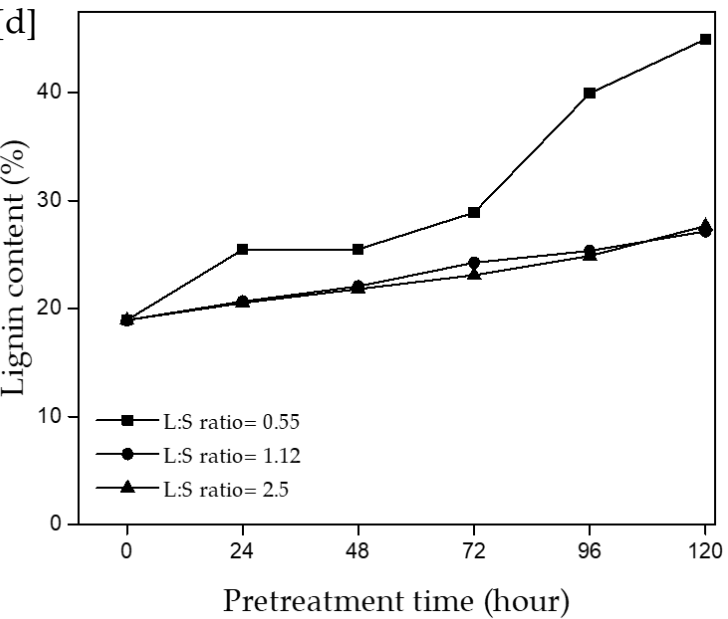

Figure 4. Effect of $\mathrm{L} / \mathrm{S}$ ratio on (a) arabinan content, (b) xylan content, (c) glucan content, and (d) lignin content. Pretreatment conditions: $\mathrm{L} / \mathrm{S}=0.55,1.12$, and $2.5 ; 0.1 \mathrm{~g}-\mathrm{NH}_{3} / \mathrm{g}$-biomass, $150^{\circ} \mathrm{C}, 24-120 \mathrm{~h}$.

Table 4. ANOVA results of glucan and xylan digestibility tests at different L/S ratios.

\begin{tabular}{|c|c|c|c|c|c|c|c|}
\hline Groups & Mean & Variance & Std. Dev. & Low & High & $F$ & $p$-Value \\
\hline \multicolumn{8}{|c|}{ Glucan digestibility } \\
\hline $\mathrm{L} / \mathrm{S}=0.55$ & 81.33 & 29.80 & 5.46 & 75.87 & 86.79 & 0.05 & 0.95 \\
\hline $\mathrm{L} / \mathrm{S}=1.12$ & 81.39 & 50.56 & 7.11 & 74.28 & 88.50 & & \\
\hline $\mathrm{L} / \mathrm{S}=2.50$ & 80.95 & 38.69 & 6.22 & 74.73 & 87.17 & & \\
\hline \multicolumn{8}{|c|}{ Xylan digestibility } \\
\hline $\mathrm{L} / \mathrm{S}=0.55$ & 69.38 & 32.68 & 5.72 & 63.67 & 75.10 & & \\
\hline $\mathrm{L} / \mathrm{S}=1.12$ & 65.64 & 17.71 & 4.21 & 61.43 & 69.85 & 11.46 & 0.00003 \\
\hline $\mathrm{L} / \mathrm{S}=2.50$ & 62.99 & 21.30 & 4.62 & 58.37 & 67.60 & & \\
\hline
\end{tabular}


(a)

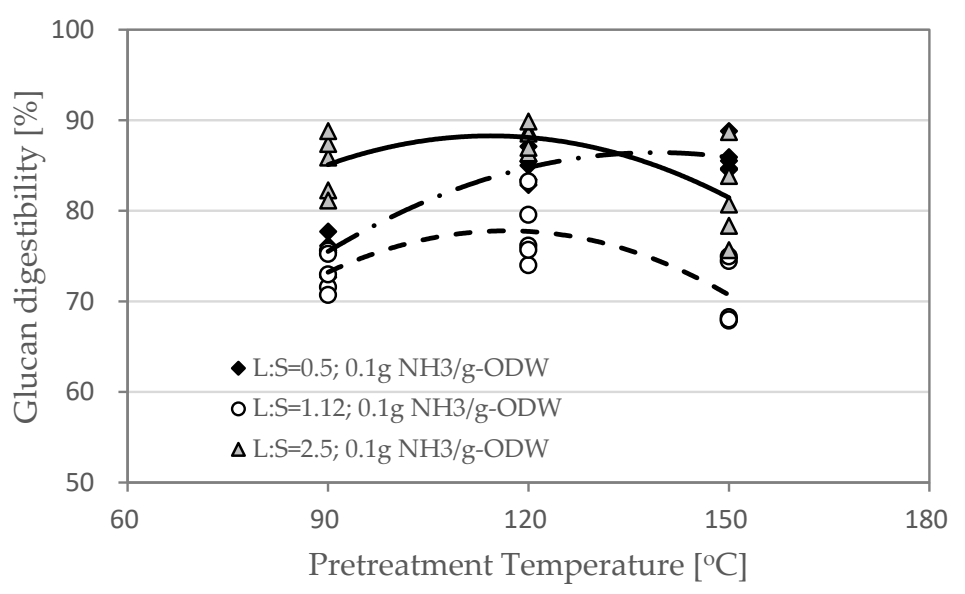

(b)

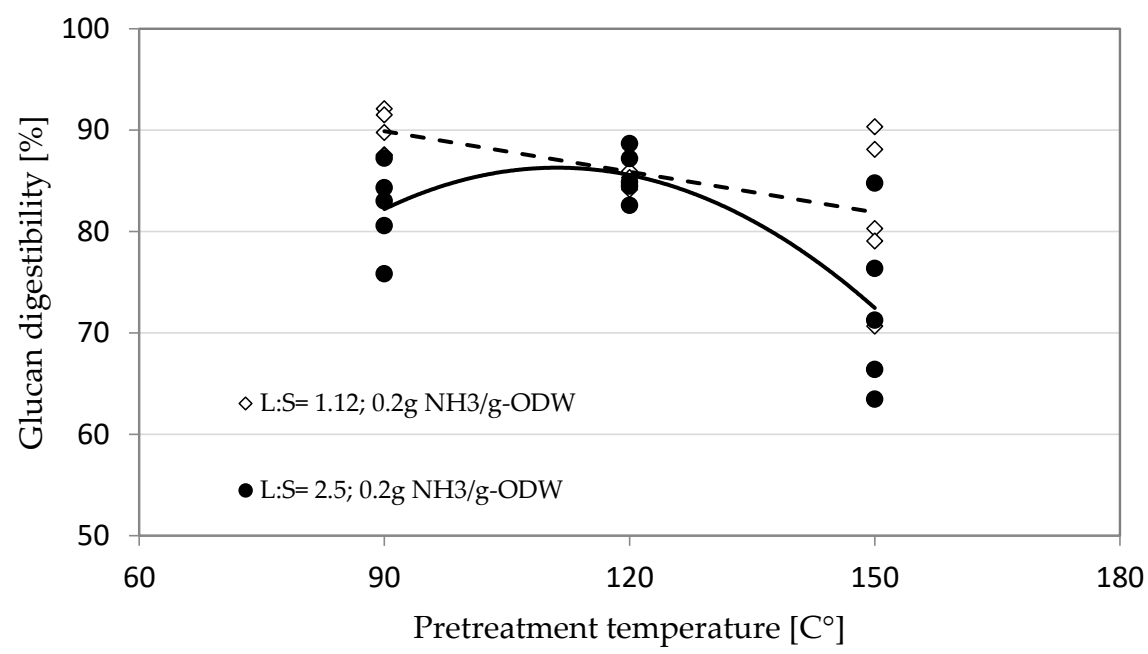

(c)

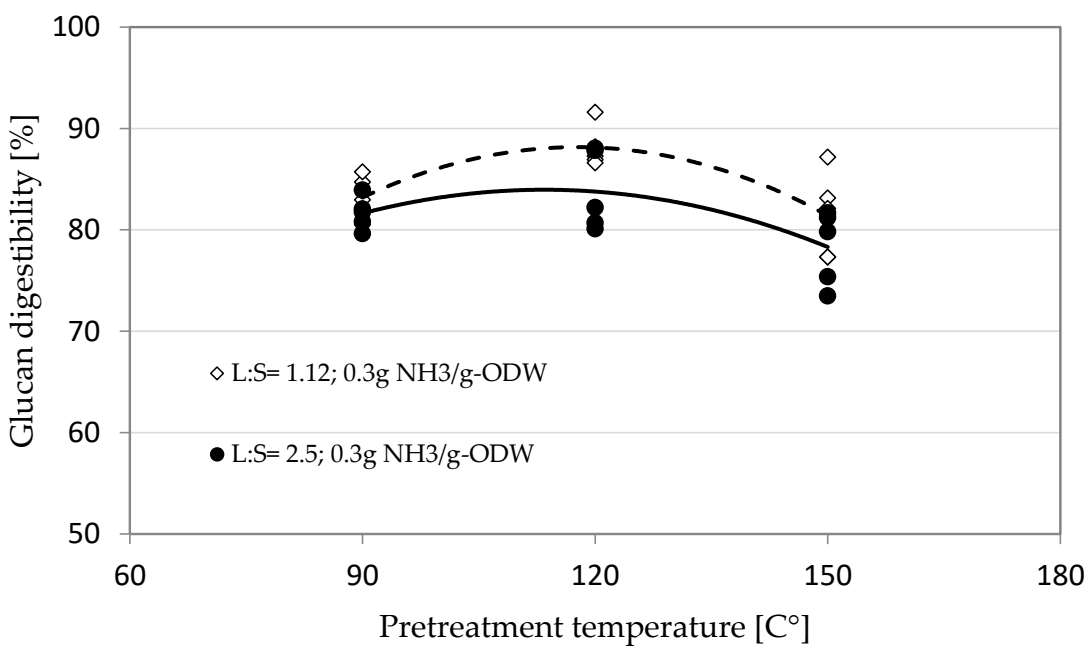

Figure 5. Effect of $\mathrm{L} / \mathrm{S}$ ratio on enzymatic digestibility of corn stover. (a) $0.1 \mathrm{~g} \mathrm{NH}_{3}$ loading, (b) $0.2 \mathrm{~g}$ $\mathrm{NH}_{3}$ loading, (c) $0.3 \mathrm{~g} \mathrm{NH}_{3}$ loading ELLA treatment conditions: $\mathrm{L} / \mathrm{S}=0.55,1.12,2.5 ; 0.1-0.3 \mathrm{~g}$ $\mathrm{NH}_{3}$ /g-biomass, $90-150{ }^{\circ} \mathrm{C}, 24-120 \mathrm{~h}$. Enzymatic hydrolysis conditions: CTech2; $15 \mathrm{FPU} / \mathrm{g}$-glucan loading; $50^{\circ} \mathrm{C}$; $150 \mathrm{rpm}$; hydrolysis time, $72 \mathrm{~h}$. 


\subsection{Residual Ammonia after ELLA Pretreatment}

Although there are many conditions that can affect enzymatic digestibility, such as ammonia loading, pretreatment temperature, and pretreatment time, it can be observed from Figure 6 that the residual ammonia in the biomass did not have any significant relation with the enzymatic hydrolysis. In addition, the residual ammonia was significantly different at different $\mathrm{L} / \mathrm{S}$ ratios $(p<0.05)$ (Table 5). When the $\mathrm{L} / \mathrm{S}$ ratio was increased, the residual ammonia increased in turn. As shown in Table 5, the mean residual ammonia increased from $0.22 \%$ to $1.65 \%(\mathrm{~L} / \mathrm{S}=0.55$ to 2.50$)$.

(a)

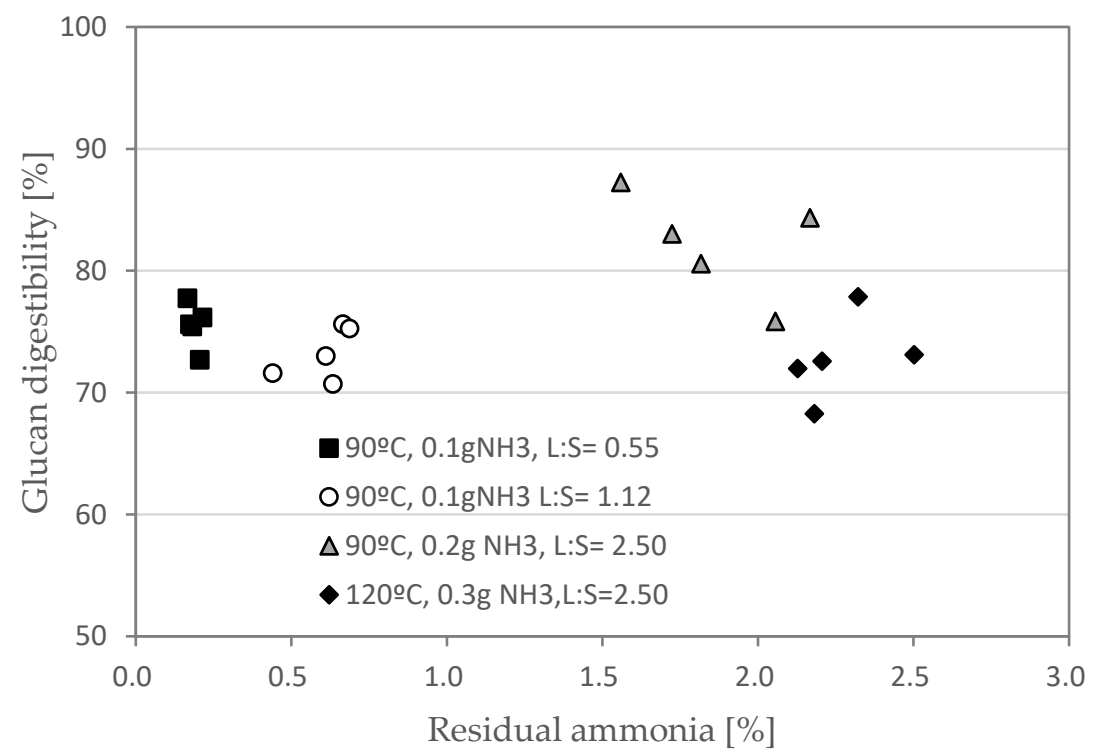

(b)

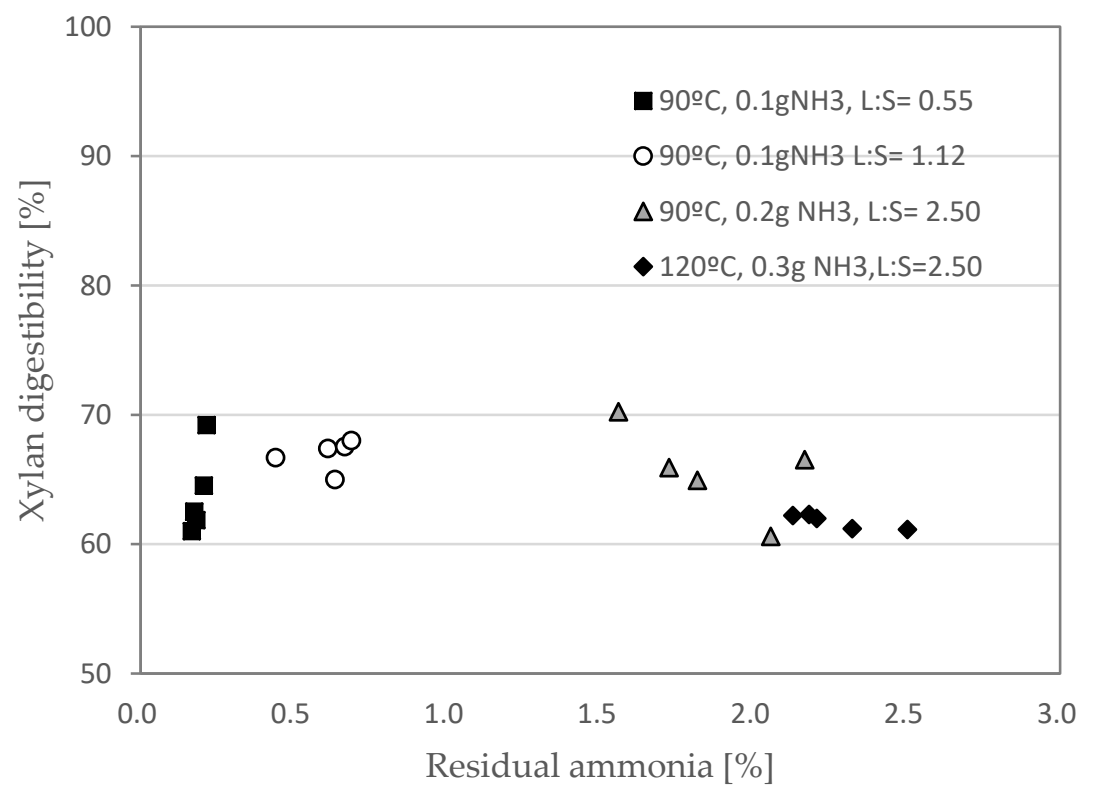

Figure 6. Effect of residual ammonia in ELLA-treated sample on (a) glucan digestibility and (b) xylan digestibility. ELLA conditions: $\mathrm{L} / \mathrm{S}=0.55-2.5 ; 0.1-0.3 \mathrm{~g}-\mathrm{NH}_{3} / \mathrm{g}$-biomass, $90-150{ }^{\circ} \mathrm{C}, 24-120 \mathrm{~h}$. Enzymatic hydrolysis conditions: CTech2; $15 \mathrm{FPU} /$ g-glucan loading; $50{ }^{\circ} \mathrm{C} ; 150 \mathrm{rpm}$; hydrolysis time, $72 \mathrm{~h}$. 
Table 5. ANOVA results of residual ammonia using different $\mathrm{L} / \mathrm{S}$ ratios.

\begin{tabular}{cccccccc}
\hline Groups & Mean & Variance & Std. Dev. & Low & High & $\boldsymbol{F}$ & $p$-Value \\
\hline $\mathrm{L} / \mathrm{S}=0.55$ & 0.22 & 0.00 & 0.05 & 0.17 & 0.27 & & \\
$\mathrm{~L} / \mathrm{S}=1.12$ & 0.58 & 0.09 & 0.30 & 0.28 & 0.89 & 45.34 & $8 \times 10^{-15}$ \\
$\mathrm{~L} / \mathrm{S}=2.50$ & 1.65 & 0.82 & 0.91 & 0.74 & 2.55 & & \\
\hline
\end{tabular}

\subsection{Simultaneous Saccharification and Fermentation (SSF)}

In this experiment, ethanol yields obtained using SSF on ELLA-treated corn stover were evaluated. The effect of the ELLA pretreatment on ethanol production was assessed. The ELLA pretreatment was conducted for $24 \mathrm{~h}$, at temperatures ranging from 90 to $150{ }^{\circ} \mathrm{C}$, with an ammonia loading of $0.1-0.3 \mathrm{~g}-\mathrm{NH}_{3} / \mathrm{g}$-biomass, and of $\mathrm{L} / \mathrm{S}=1.12$ and $2.50 . \mathrm{S}$. cerevisiae $\mathrm{D}_{5} \mathrm{~A}$ was selected with a $15 \mathrm{FPU} /$ g-glucan loading. A short pretreatment time $(24 \mathrm{~h})$ was chosen to make the pretreatment more economically feasible. The conditions, glucan digestibility, and ethanol yields are listed in Table 6.

Table 6. Effects of ELLA treatment conditions on ethanol yield.

\begin{tabular}{|c|c|c|c|c|c|}
\hline L/S Ratio & $\begin{array}{l}\text { Time } \\
{[\mathrm{h}]}\end{array}$ & $\begin{array}{c}\mathrm{NH}_{3} \\
\text { [g-NH} / \mathrm{g}-\text {-Biomass] }\end{array}$ & $\begin{array}{c}\text { Temperature } \\
{\left[{ }^{\circ} \mathrm{C}\right]}\end{array}$ & $\begin{array}{c}\text { Ethanol Yield } \\
{[\%]}\end{array}$ & $\begin{array}{c}\text { Glucan Digestibility } \\
{[\%]}\end{array}$ \\
\hline \multirow{9}{*}{1.12} & \multirow{9}{*}{24} & 0.1 & 90 & $80.7 \pm 0.3$ & $71.6 \pm 0.3$ \\
\hline & & 0.2 & 90 & $81.2 \pm 0.5$ & $91.7 \pm 0.5$ \\
\hline & & 0.3 & 90 & $81.9 \pm 0.3$ & $84.7 \pm 0.2$ \\
\hline & & 0.1 & 120 & $80.7 \pm 0.5$ & $74.0 \pm 0.4$ \\
\hline & & 0.2 & 120 & $83.6 \pm 0.3$ & $88.7 \pm 0.3$ \\
\hline & & 0.3 & 120 & $82.1 \pm 0.2$ & $88.2 \pm 0.5$ \\
\hline & & 0.1 & 150 & $79.7 \pm 0.2$ & $74.4 \pm 0.3$ \\
\hline & & 0.2 & 150 & $81.4 \pm 0.5$ & $90.4 \pm 0.5$ \\
\hline & & 0.3 & 150 & $82.9 \pm 0.2$ & $87.2 \pm 0.3$ \\
\hline \multirow{9}{*}{2.50} & \multirow{9}{*}{24} & 0.1 & 90 & $83.7 \pm 0.4$ & $82.3 \pm 0.2$ \\
\hline & & 0.2 & 90 & $82.3 \pm 0.3$ & $87.2 \pm 0.2$ \\
\hline & & 0.3 & 90 & $84.2 \pm 0.5$ & $80.8 \pm 0.3$ \\
\hline & & 0.1 & 120 & $82.8 \pm 0.3$ & $88.8 \pm 0.5$ \\
\hline & & 0.2 & 120 & $79.5 \pm 0.2$ & $87.2 \pm 0.5$ \\
\hline & & 0.3 & 120 & $83.9 \pm 0.4$ & $77.9 \pm 0.5$ \\
\hline & & 0.1 & 150 & $83.1 \pm 0.5$ & $85.5 \pm 0.4$ \\
\hline & & 0.2 & 150 & $84.5 \pm 0.2$ & $84.8 \pm 0.3$ \\
\hline & & 0.3 & 150 & $85.4 \pm 0.2$ & $81.2 \pm 0.3$ \\
\hline
\end{tabular}

SSF test conditions: S. cerevisiae $\mathrm{D}_{5} \mathrm{~A}, 3 \%$ w/v glucan, $15 \mathrm{FPU}$ of CTech $2 /$ g-glucan loading, YP $5 \mathrm{X}$ medium ( $2 \%$ yeast extract, $1 \%$ peptone), $\mathrm{pH}=4.8,37^{\circ} \mathrm{C}, 150 \mathrm{rpm}, 96 \mathrm{~h}$. The data in the table show the mean value and standard deviation (SD).

It can be observed that increasing the $\mathrm{L} / \mathrm{S}$ ratio caused significant changes in the ethanol yield. The analysis of variance (ANOVA) results are summarized in Table 7 . The variance between the ethanol yield at different $\mathrm{L} / \mathrm{S}$ ratios was significant $(p=0.03<0.05)$, with high $F$-values $(F=11.3)$, indicating that the inter-group variability was greater than the intra-group variability. We know that $\mathrm{L} / \mathrm{S}$ ratios are related to the ratio of oven-dry weight biomass to ammonia and water in pretreated corn stover. Increasing the $\mathrm{L} / \mathrm{S}$ ratio increases the moisture content of the biomass. Previous studies have shown that water molecules play an important role in binding ammonium ions during the pretreatment reaction. For example, in the LMAA pretreatment, the SSF of the $70 \%$ moisture sample resulted in the highest ethanol concentration $(24.9 \mathrm{~g} / \mathrm{L}$ at $120 \mathrm{~h}$ fermentation). Furthermore, the ELLA pretreatment resulted in a similar situation. The corn stover with a higher moisture content retained more ammonium ions. When the residual ammonia content increased from $0.7 \%$ to $2.4 \%$ and the moisture content of the corn stover increased from $50 \%$ to $70 \%$, the ethanol 
yield slightly increased, from $82.9 \%$ to $85.4 \%$ (pretreatment conditions: $\mathrm{L} / \mathrm{S}=1.12,2.50$, 0.3 g- $\mathrm{NH}_{3} /$ g-biomass, $150{ }^{\circ} \mathrm{C}, 24 \mathrm{~h}$. SSF conditions: $15 \mathrm{FPU} / \mathrm{g}$-glucan of CTech $2,3 \%$ w/v glucan, $\left.37^{\circ} \mathrm{C}, 150 \mathrm{rpm}\right)$. However, there was no significant difference in ethanol yield, with differences in the pretreatment temperature $(p=0.29>0.05)$ and ammonia loading $(p=0.24>0.05)$ at $\mathrm{L} / \mathrm{S}=2.50$ (Table 8$)$. The highest ethanol yield achieved in this case was $85.4 \%$. The ethanol concentration was $14.5 \mathrm{~g} / \mathrm{L}$ at $96 \mathrm{~h}$, with glucan and xylan digestibilities of $81.2 \%$ and $60.1 \%$, respectively (pretreatment conditions: $\mathrm{L} / \mathrm{S}=2.50$, $0.3 \mathrm{~g}-\mathrm{NH}_{3} / \mathrm{g}$-biomass, $150{ }^{\circ} \mathrm{C}, 24 \mathrm{~h}$. SSF conditions: $15 \mathrm{FPU} / \mathrm{g}$-glucan of CTech2, 3\% w/v glucan, $\left.37^{\circ} \mathrm{C}, 150 \mathrm{rpm}\right)$.

Table 7. ANOVA results of ethanol yields at different $\mathrm{L} / \mathrm{S}$ ratios.

\begin{tabular}{cccccccc}
\hline Groups & Mean & Variance & Std. Dev. & Low & High & F & $p$-Value \\
\hline L/S $=1.12$ & 81.58 & 1.43 & 1.20 & 80.38 & 82.77 & \multirow{2}{*}{5.86} & 0.03 \\
L/S $=2.50$ & 83.26 & 2.89 & 1.70 & 81.56 & 84.96 & & \\
\hline
\end{tabular}

ELLA treatment: $0.1-0.3$ g-NH 3 /g-biomass, $90-150{ }^{\circ} \mathrm{C}, 24-120 \mathrm{~h}, \mathrm{~L} / \mathrm{S}=1: 1.12-1: 2.50$. Std. Dev: Standard deviation

Table 8. ANOVA results of ethanol yields at different pretreatment temperatures and ammonia loadings (at $\mathrm{L} / \mathrm{S}=2.50)$.

\begin{tabular}{|c|c|c|c|c|c|c|c|}
\hline $\begin{array}{c}\text { Groups } \\
(\mathrm{L} / \mathrm{S}=2.50)\end{array}$ & Mean & Variance & Std. Dev. & Low & High & $\mathbf{F}$ & $p$-Value \\
\hline $90^{\circ} \mathrm{C}$ & 83.40 & 0.97 & 0.99 & 82.42 & 84.39 & \multirow{3}{*}{1.55} & \multirow{3}{*}{0.29} \\
\hline $120^{\circ} \mathrm{C}$ & 82.07 & 5.24 & 2.29 & 79.78 & 84.36 & & \\
\hline $150^{\circ} \mathrm{C}$ & 84.33 & 1.34 & 1.16 & 83.17 & 85.49 & & \\
\hline $0.1 \mathrm{~g}-\mathrm{NH}_{3} / \mathrm{g}$-biomass & 83.20 & 0.21 & 0.46 & 82.74 & 83.66 & \multirow{3}{*}{1.82} & \multirow{3}{*}{0.24} \\
\hline $0.2 \mathrm{~g}-\mathrm{NH}_{3} / \mathrm{g}$-biomass & 82.10 & 6.28 & 2.51 & 79.59 & 84.61 & & \\
\hline $0.3 \mathrm{~g}-\mathrm{NH}_{3} / \mathrm{g}$-biomass & 84.50 & 0.63 & 0.79 & 83.71 & 85.29 & & \\
\hline
\end{tabular}

ELLA treatment: $0.1-0.3$ g- $\mathrm{NH}_{3} / \mathrm{g}$-biomass, $90-150{ }^{\circ} \mathrm{C}, 24-120 \mathrm{~h}, \mathrm{~L} / \mathrm{S}=2.50$. Std. Dev: Standard deviation.

\subsection{Mass Balance}

Figure 7 summarizes the mass balance of the ELLA pretreatment under optimal conditions ( $\mathrm{L} / \mathrm{S}=2.50,0.1 \mathrm{~g}-\mathrm{NH}_{3} / \mathrm{g}$-biomass, $150{ }^{\circ} \mathrm{C}, 24 \mathrm{~h}$ ). The residual ammonia at $\mathrm{L} / \mathrm{S}=2.50$ was approximately $1.7 \%$. Thereafter, $1 \%(w / v)$ glucan in treated corn stover was digested with the enzyme CTech 2 at $50{ }^{\circ} \mathrm{C}$ and $150 \mathrm{rpm}$ for $72 \mathrm{~h}$. The highest glucan and xylan digestibility values at an enzyme loading of 15 FPU-CTec2/g glucose were obtained at $81.2 \%$ and $61.1 \%$, respectively. Thereafter, $3 \%(w / v)$ glucan in treated corn stover was fermented using the SSF method, with S. cerevisiae $\mathrm{D}_{5} \mathrm{~A}$ and enzyme CTech2. The highest ethanol yield achieved in SSF was $85.4 \%$. The ethanol concentration was $14.5 \mathrm{~g} / \mathrm{L}$ at $96 \mathrm{~h}$ (pretreatment conditions: $\mathrm{L} / \mathrm{S}=2.50,0.1 \mathrm{~g}-\mathrm{NH}_{3} / \mathrm{g}$-biomass, $150{ }^{\circ} \mathrm{C}, 24 \mathrm{~h}$. SSF conditions: microorganism $S$. cerevisiae $\mathrm{D}_{5} \mathrm{~A}, 15 \mathrm{FPU} / \mathrm{g}$-glucan of CTech2, 3\% w/v glucan, $37^{\circ} \mathrm{C}, 150 \mathrm{rpm}$ ). 


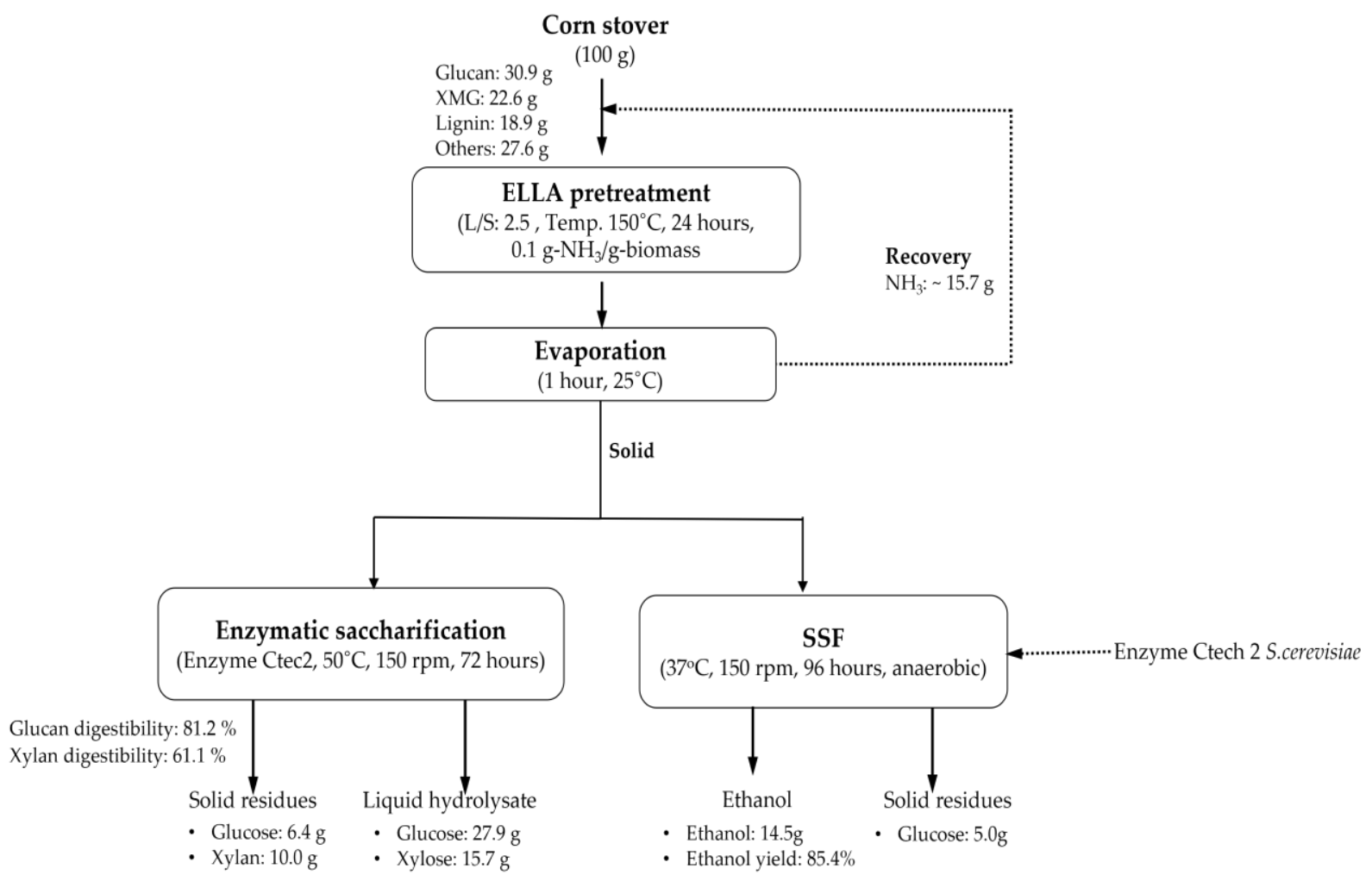

Figure 7. Schematic diagram and mass balance of production process for ethanol and glucose using ELLA pretreatment and SSF.

\section{Conclusions}

As per the experiment, ELLA pretreatment of corn stover shows promise for secondgeneration fuel production because it requires minimal chemical input and it is easy to handle. This method enhanced the enzymatic saccharification of the corn stover. The glucan and xylan digestibility values with an enzyme loading of 15 FPU-CTec2/g-glucose were $81.2 \%$ and $61.1 \%$, respectively. The highest ethanol yield achieved on the SSF test after $96 \mathrm{~h}$ of fermentation was $85.4 \%$. The ethanol concentration was $14.5 \mathrm{~g} / \mathrm{L}$ (pretreatment conditions: $\mathrm{L} / \mathrm{S}=2.50,0.1 \mathrm{~g}-\mathrm{NH}_{3} / \mathrm{g}$-biomass, $150{ }^{\circ} \mathrm{C}, 24 \mathrm{~h}$. SSF conditions: microorganism S. cerevisiae $\mathrm{D}_{5} \mathrm{~A}, 15 \mathrm{FPU} /$ g-glucan of $\mathrm{CTech} 2,3 \%$ w/v glucan, $37^{\circ} \mathrm{C}, 150 \mathrm{rpm}$ ).

However, it should be noted that the results obtained in this study cannot be directly applied to the mass production of bioethanol. Future research should find an optimal model for commercialization and optimal operating conditions for any future scale-up. In addition, follow-up studies should be performed on the design of the continuous fermentation process and to test whether the results presented in this study can be repeated.

Author Contributions: T.D.T.L. and V.P.N.T. conducted the experiments, summarized the data, and drafted the manuscript as the first authors. M.T.T.N. conducted the sample analysis, pretreatment, and data analysis as the co-author. As the co-corresponding authors, T.H.K. and K.K.O. designed the overall study and experiments, interpreted the results, wrote the manuscript, and finalized the manuscript. All authors have read and agreed to the published version of the manuscript.

Funding: This work was supported by the R\&D program of the Korean Institute of Energy Technology Evaluation and Planning (KETEP), with a grant funded by the Ministry of Trade, Industry \& Energy (MOTIE), Korea (No. 20183030092080).

Institutional Review Board Statement: Not applicable.

Informed Consent Statement: Not applicable.

Data Availability Statement: Not applicable. 
Conflicts of Interest: The authors declare no conflict of interest.

\section{References}

1. Sims, R.E.; Mabee, W.; Saddler, J.N.; Taylor, M. An overview of second generation biofuel technologies. Bioresour. Technol. 2010, 101, 1570-1580. [CrossRef] [PubMed]

2. Somerville, C.; Youngs, H.; Taylor, C.; Davis, S.C.; Long, S.P. Feedstocks for lignocellulosic biofuels. Science 2010, 329 , 790-792. [CrossRef] [PubMed]

3. Naik, S.N.; Goud, V.V.; Rout, P.K.; Dalai, A.K. Production of first and second generation biofuels: A comprehensive review. Renew. Sustain. Energy Rev. 2010, 14, 578-597. [CrossRef]

4. Abdeshahian, P.; Dashti, M.; Kalil, M.; Yusoff, W. Production of biofuel using biomass as a sustainable biological resource. Biotechnology 2010, 9, 274-282. [CrossRef]

5. Josling, T.; Blandford, D.; Earley, J. Biofuel and Biomass Subsidies in the US, EU and Brazil: Towards a Transparent System of Notification; IPC Position Paper; International Food and Agricultural Trade Policy Council: Washington, DC, USA, 2010.

6. Marshall, L.; Sugg, Z. Corn stover for ethanol production: Potential and pitfalls. WRI Policy Note Biofuels No 2009, 4, 1-10.

7. Sheehan, J.; Aden, A.; Paustian, K.; Killian, K.; Brenner, J.; Walsh, M.; Nelson, R. Energy and environmental aspects of using corn stover for fuel ethanol. J. Ind. Ecol. 2003, 7, 117-146. [CrossRef]

8. Brown, T.R.; Brown, R.C. A review of cellulosic biofuel commercial-Scale projects in the United States. Biofuels Bioprod. Biorefin. 2013, 7, 235-245. [CrossRef]

9. Humbird, D.; Aden, A. Biochemical Production of Ethanol from Corn Stover: 2008 State of Technology Model; National Renewable Energy Lab (NREL): Golden, CO, USA, 2009.

10. Kim, T.H.; Lee, Y.Y.; Sunwoo, C.; Kim, J.S. Pretreatment of corn stover by low-liquid ammonia recycle percolation process. Appl. Biochem. Biotechnol. 2006, 133, 41-57. [CrossRef]

11. Hu, F.; Ragauskas, A. Pretreatment and lignocellulosic chemistry. Bioenergy Res. 2012, 5, 1043-1066. [CrossRef]

12. Davison, B.H.; Parks, J.; Davis, M.F.; Donohoe, B.S. Plant cell walls: Basics of structure, chemistry, accessibility and the influence on conversion. In Aqueous Pretreatment of Plant Biomass for Biological and Chemical Conversion to Fuels and Chemicals; John Wiley \& Son Ltd.: Hoboken, NJ, USA, 2013; pp. 23-38.

13. Charlier, L.; Mazeau, K. Molecular modeling of the structural and dynamical properties of secondary plant cell walls: Influence of lignin chemistry. J. Phys. Chem. B 2012, 116, 4163-4174. [CrossRef] [PubMed]

14. Behera, S.; Arora, R.; Nandhagopal, N.; Kumar, S. Importance of chemical pretreatment for bioconversion of lignocellulosic biomass. Renew. Sustain. Energy Rev. 2014, 36, 91-106. [CrossRef]

15. Kim, J.S.; Lee, Y.; Kim, T.H. A review on alkaline pretreatment technology for bioconversion of lignocellulosic biomass. Bioresour. Technol. 2016, 199, 42-48. [CrossRef] [PubMed]

16. Galbe, M.; Wallberg, O. Pretreatment for biorefineries: A review of common methods for efficient utilisation of lignocellulosic materials. Biotechnol. Biofuels 2019, 12, 294. [CrossRef] [PubMed]

17. Yoo, C.G.; Nghiem, N.P.; Hicks, K.B.; Kim, T.H. Pretreatment of corn stover using low-moisture anhydrous ammonia (LMAA) process. Bioresour. Technol. 2011, 102, 10028-10034. [CrossRef]

18. Cayetano, R.D.A.; Kim, T.H. Effects of low moisture anhydrous ammonia (LMAA) pretreatment at controlled ammoniation temperatures on enzymatic hydrolysis of corn stover. Appl. Biochem. Biotechnol. 2017, 181, 1257-1269. [CrossRef] [PubMed]

19. Nguyen Truong, V.P. Pretreatment of corn stover using extremely low liquid ammonia method. Master's Thesis, Kongju National University, Cheonan, Korea, 2017.

20. Yoo, C.G.; Kim, H.; Lu, F.; Azarpira, A.; Pan, X.; Oh, K.K.; Kim, J.S.; Ralph, J.; Kim, T.H. Understanding the physicochemical characteristics and the improved enzymatic saccharification of corn stover pretreated with aqueous and gaseous ammonia. BioEnergy Res. 2016, 9, 67-76. [CrossRef]

21. Ioelovich, M.; Morag, E. Study of enzymatic hydrolysis of mild pretreated lignocellulosic biomasses. BioResources 2012, 7, 1040-1052. [CrossRef]

22. Li, X. Bioethanol Production from Lignocellulosic Feedstock Using Aqueous Ammonia Pretreatment and Simultaneous Saccharification and Fermentation (SSF): Process development and optimization. Master's Thesis, Iowa State University, Ames, IA, USA, 2010 